\title{
Minat siswa sekolah menengah pertama terhadap pembelajaran atletik
}

\author{
Maratona Sakti Utami *, Eddy Purnomo \\ Fakultas IImu Keolahragaan Universitas Negeri Yogyakarta. \\ Jalan Colombo No. 1 Yogyakarta 55281, Indonesia. \\ Corresponding Author. Email: maratonasakti15.msu@gmail.com
}

\begin{abstract}
Abstrak
Penelitian ini dilatarbelakangi oleh belum maksimalnya pembelajaran pendidikan jasmani pada materi atletik dan belum diketahuinya minat siswa terhadap pembelajaran atletik. Penelitian ini bertujuan untuk mengetahui minat siswa kelas VIII SMP Negeri 2 Jenawi Kabupaten Karanganyar dalam mengikuti pembelajaran atletik. Penelitian ini merupakan penelitian dekriptif kuantitatif. Metode yang digunakan adalah metode survei dengan teknik pengumpulan data menggunakan angket. Subjek penelitian ini adalah seluruh siswa kelas VIII kecuali kelas VIII C karena dijadikan sebagai uji coba penelitian, dari 4 kelas dipilih 25 siswa dengan cara diundi, sehingga mendapatkan populasi sebanyak 100 siswa. Teknik analisis yang dilakukan adalah menuangkan frekuensi ke dalam bentuk persentase. Hasil penelitian ini menunjukkan bahwa minat siswa SMP Negeri 2 Jenawi Kabupaten Karanganyar kelas VIII terhadap pembelajaran atletik adalah cukup. Dengan pertimbangan frekuensi terbanyak berada pada kategori sedang dengan persentase 83,00\%. Persentase minat siswa SMP Negeri 2 Jenawi Kabupaten Karanganyar kelas VIII terhadap pembelajaran atletik yang berkategori sangat tinggi adalah 0,00\%, tinggi $11,00 \%$, sedang $83,00 \%$, kurang 6,00\% dan sangat kurang $0,00 \%$.

Kata Kunci: minat, pembelajaran atletik, pendidikan jasmani
\end{abstract}

\section{The interest of students of junior high school on athletic learning}

\begin{abstract}
.
The background problem of this research because not maximal yet in physical education, learning on athletic material and the students' interest in athletic learning was unknown yet. This research aimed to know the students' interest in athletic learning at the eighth-grade students of SMP 2 Jenawi Karanganyar regency. This research was quantitative descriptive research. The method used in this research was survey method while the technique of collecting the data used questionnaire. The research subject was the whole of eighth-grade students except VIII C class because it was used as a research trial, from four classes was chosen 25 students randomly, it got a population of 100 students. The technique of analyzing the data used the frequency in the form of the percentage. The result of the research showed that students' interest in athletic learning at the eighth-grade students of SMP Negeri 2 Jenawi Karanganyar regency was enough. With consideration of the most frequency was enough, with the percentage of $83 \%$. The percentage of students' interest in athletic learning at the eighth-grade students of SMP Negeri 2 Jenawi Karanganyar regency who had the highest category was $0,00 \%$, high $11,00 \%$, enough $83 \%$, low $6,00 \%$ and the lowest was $0,00 \%$.
\end{abstract}

Keywords: interest, athletic learning, physical education

\section{PENDAHULUAN}

Sekolah merupakan suatu tempat dimana seseorang mendapatkan pendidikan secara formal (Montessori, 2012; Sudarsana, 2016), sekolah memiliki tujuan untuk meningkatkan mutu pendidikan dengan cara mendidik, membimbing dan mendewasakan siswa-siswi (Basri, 2018). Sekolah memiliki berbagai macam mata pelajaran untuk membekali meningkatkan pengetahuan agar ilmu yang diberikan berguna untuk jenjang sekolah yang selanjutnya. Mata pelajaran yang diadakan di sekolah antara lain Pendidikan Agama, Pendidikan Kewarganegaraan, Bahasa, Matematika, IPA, IPS, seni dan budaya, Pendidikan Jasmani Olahraga dan Kesehatan, keterampilan atau kejuruan, serta muatan lokal. 
Pendidikan Jasmani Olahraga dan Kesehatan (PJOK) merupakan mata pelajaran yang penting, karena membantu mengembangkan siswa sebagai individu dan mahkluk sosial agar tumbuh dan berkembang secara wajar (Wibowo, 2017). Hal Ini dikarenakan pelaksanaannya mengutamakan aktivitas jasmani khususnya olahraga dan kebiasaan hidup sehat. Dengan adanya pendidikan jasmani olahraga dan kesehatan, maka potensi diri dari seseorang akan dapat berkembang.

Materi pembelajaran atletik merupakan salah satu cabang olahraga yang diajarkan dalam pembelajaran PJOK di SMP. Maksud dan tujuan diajarkannya cabang olahraga atletik yaitu untuk membantu perkembangan dan pertumbuhan siswa dalam kemampuan gerak siswa serta mengenalkan nomor-nomor cabang olahraga atletik (Murdiyanto, 2010). Nomornomor olahraga atletik diantaranya jalan, lari, lompat dan lempar. Pembelajaran yang efektif, efisien dan terencana diharapkan dapat menjadikan proses pembelajaran atletik berjalan dengan baik.

Pembelajaran merupakan suatu proses transfer ilmu dari guru kepada siswa dengan menggunakan cara atau metode yang tepat agar siswa dapat memahami materi yang disampaikan oleh guru. Atletik merupakan materi pembelajaran yang sudah ada mulai dari SD hingga SMA, bahkan di beberapa perguruan tinggi atletik merupakan mata kuliah umum. Sedangkan bagi mahasiswa jurusan Pendidikan Olahraga atletik adalah matakuliah yang wajib ditempuh bagi mahasiswa. Atletik adalah materi pembelajaran yang sangat penting karena atletik merupakan induk atau ibu dari cabang olahraga.

Kendala pembelajaran dapat di pengaruhi oleh beberapa faktor diantaranya adalah peran guru. Peran guru sangat berpengaruh terhadap berhasil dan tidak berhasilnya pembelajaran atletik karena keterbatasan metode-metode dan tidak adanya modifikasi permainan atau alat yang baru siswa menjadi tidak bersemangat dan mudah merasa bosan saat mengikuti pembelajaran. Apabila pembelajaran atletik di ikuti dengan rasa bosan dan tidak senang maka kebugaran dan kesegaran jasmani siswa akan rendah dan minta siswa dalam mengikuti pembelajaran atletik semakin menurun.

Berdasarkan hasil observasi pembelajaran atletik dan perbincangam dengan siswa kelas VIII di SMP N 2 Jenawi kabupaten Karanganyar, diketahui bahwa masih ada siswa yang merasa bosan dan tidak bersemangat saat pembelajaran atletik, di sebabkan karena keterbatasan alat sehingga siswa harus bergantian untuk menggunakan alat tersebut. Kurangnya kreativitas guru untuk memodifikasi alat bantu, membuat beberapa siswa merasa bahwa pembelajaran atletik merupakan pembelajaran yang sulit, sehingga siswa kurang perhatian dan kurang bersungguh-sugguh dalam mengikuti pembelajaran atletik.

Kurikulum kelas VIII di SMP N 2 Jenawi menggunakan kurikulum KTSP (Kurikulum Tingkat Satuan Pendidikan). Standar kompetensi yang harus di kuasai oleh siswa kelas VIII semester I adalah (1) Mempraktikkan berbagai teknik dasar permainan dan olahraga dan nilai-nilai yang terkandung di dalamnya. (2) Mempraktikkan latihan kebugaran dalam bentuk latihan sirkuit dan nilai-nilai yang terkandung di dalamnya. (3) Mempraktikkan teknik dasar senam lantai dan nilai-nilai yang terkandung di dalamnya. (4) Mempraktikkan senam irama dengan alat dan nilai-nilai yang terkandung di dalamnya. (5) Mempraktikkan teknik dasar renang gaya bebas dan nilai-nilai yang terkandung di dalamnya. (6) Menerapkan budaya hidup sehat. Standar kompetensi kelas VIII semester II adalah (1) Mempraktikkan berbagai teknik dasar permainan dan olahraga dan nilai-nilai yang terkandung di dalamnya. (8) Mempraktikkan latihan kebugaran dalam bentuk latihan sirkuit dan nilai-nilai yang terkandung di dalamnya. (2) Mempraktikkan teknik dasar senam lantai dan nilai-nilai yang terkandung di dalanya. (3) Mempraktikkan senam irama dengan alat dan nilai-nilai yang terkandung di dalamnya. (4) Mempraktikkan teknik dasar renang gaya dada dan nilai-nilai yang terkandung di dalamnya. (5) Mempraktikkan penjelajahan di sekitar sekolah dan nilainilai yang terkandung di dalamnya. (6) Menerapkan budaya hidup sehat.

Pembelajaran atletik apabila diikuti dengan semangat dan rasa senang akan membuat kesegaran dan kebugaran jasmani siswa semakin meningkat, kondisi tubuh menjadi kuat dan siswa tidak cepat lelah. Dengan metode dan modifikasi permainan akan membuat siswa lebih antusias dan tidak mudah bosan dengan pembelajaran atletik, sehingga minat siswa dalam pembelajaran atletik akan meningkat. 


\section{METODE}

Penelitian ini merupakan penelitian deskriptif yang bertujuan untuk mengetahui seberapa tinggi minat siswa kelas VIII SMP Negeri 2 Jenawi Kabupaten Karanganyar dalam mengikuti pembelajaran atletik di sekolah. Menurut Arikunto (2014, p. 234) Penelitian deskriptif tidak dimaksudkan untuk menguji hipotesis tertentu, tetapi hanya menggambarkan "apa adanya" tentang suatu variabel, gejala atau keadaan. Metode yang digunakan adalah survei, teknik pengambilan data menggunakan angket, dengan menggunakan skala psikologis sebagai pengumpulan data.

Penelitian ini dilakukan pada tahun ajaran 2018/2019 semester gasal, yaitu pada tanggal 16 Juli sampai dengan Agustus 2018. Penelitian ini dilakukan di SMP Negeri 2 Jenawi Jenawi, Karanganyar. Populasi adalah keseluruhan subjek penelitian yang berada dalam suatu tempat yang memenuhi syarat tertentu yang berkaitan dengan masalah penelitian Arikunto (2006: 130). Populasi dalam penelitian ini adalah seluruh siswa kelas VIII di SMP N 2 Jenawi Kabupaten Karanganyar yang tercatat di SMP N 2 Jenawi yaitu, kelas VIII A, VIII B, VIII D dan VIII E yang berjumlah 126 siswa.

Menurut Arikunto (2006, p.131) menyatakan bahwa sampel adalah sebagian atau wakil populasi yang akan kita teliti. sampel yang akan diambil dalam penelitian ini adalah siswa kelas VIII SMP Negeri 2 Jenawi yang berjumlah 126 siswa dari kelas VIII A, VIII B, VIII D dan VIII E. Dari semua siswa kelas VIII di SMP Negeri 2 Jenawi memiliki kesempatan yang sama untuk menjadi sampel penelitian. Dari total 5 kelas peneliti hanya mengambil 4 kelas yaitu kelas VIII A, VIII B, VIII D dan VIII E, karena kelas VIII C sudah dilakukan sebangai uji coba instrumen.

Arikunto (2006: 134) menyatakan bahwa apabila subjeknya kurang dari 100, maka lebih baik diambil semua sehingga penelitiannya merupakan penelitian populasi. Tetapi jika jumlah subjeknya besar, dapat diambil antara $10-15 \%$ atau $20-25 \%$ atau lebih. Maka sampel yang digunakan adalah Quota Sampling dengan cara memilih 25 siswa di masing-masing kelas sehingga mendapatkan populasi sebanyak 100 siswa. Pengambilan sampel dilakukan dengan cara undian, karena dengan cara undian dapat meminimalkan ketidakadilan dalam memilih sampel. Dari setiap kelas akan di undi dan setiap kelas akan diambil 25 siswa untuk menjadi sampel.

Instrumen penelitian adalah alat atau fasilitas yang digunakan oleh peneliti dalam mengumpulkan data agar pekerjaannya lebih mudah dan hasilnya lebih baik, dalam arti lebih cermat, lengkap dan sistematis sehingga mudah diolah (Arikunto 2006: 160). Instrumen dan teknik pengumpulan data penelitian yang digunakan dalam penelitian ini menggunakan skala psikologis sebagai alat pengambil data yang mengadopsi dari angket Dwi Hari Subekti (2007), tentang Minat Siswa SMK YPKK 2 Sleman Kelas XI Terhadap Pembelajaran Atletik. Skala psikologis adalah sejumlah pertanyaan tertulis yang digunakan untuk memperoleh informasi dari responden dalam arti mengungkap aspek-aspek seperti: tendensi, sikap, minat, kecamasan dan lain-lain.

Penelitian ini menggunakan angket untuk mengumpulkan data, dengan angket lebih memberikan kesempatan kepada siswa untuk memberikan informasi yang akurat, baik dan benar. Dalam penelitian ini angket yang digunakan adalah angket tertutup agar dapat memudahkan siswa untuk mengisinya. Responden langsung menjawab pertanyaan yang telah di sediakan dengan cara memberi tanda silang atau centang pada jawaban yang dipilih.

Alternatif jawaban dalam angket ini menggunakan skala Likert merupakan jenis skala yang digunakan untuk mengukur variabel penelitian. Skala Likert dinyatakan dalam bentuk pernyataan untuk dinilai oleh responden, apakah pernyataan tersebut di dukung atau tidak oleh responden. Pernyataan yang diajukan ada 2 (dua) kategori, yakni pernyataan positif dan negatif. Setiap butir pernyataan mengungkap minat responden dan disediakan empat alternatif jawaban, yaitu: Sangat Setuju (SS), Setuju (S), Tidak Setuju (TS), Sangat Tidak Setuju (STS).

Teknik pengumpulan data yang akan digunakan adalah dengan pemberian instrumen penelitian kepada responden yang menjadi subjek dalam penelitian. Adapun mekanismenya 
adalah sebagai berikut: (1) Peneliti membagikan kuesioner penelitian dan meminta responden untuk mengisi kuesioner tersebut; (2) Peneliti menjelaskan cara pengisian angket; (3) Dapat dijawab oleh responden menurut kecepatan masing-masing dan menurut waktu luang responden; dan (4) Peneliti mengambil kuesioner setelah diisi dengan lengkap

Setelah butir instrumen atau angket di konsultasikan, langkah selanjutnya yang akan dilakukan yaitu menguji cobakan kepada responden atau siswa yang tidak termasuk dalam sampel penelitian yang mempunyai ciri-ciri yang sama dengan responden yang sesungguhnya. Untuk mengetahui validitas perlu dilakukan uji coba instrumen. Untuk mendapatkan data penelitian yang sesungguhnya instrumen yang akan digunakan di uji cobakan terlebih dahulu. Uji coba instrumen dilakukan pada kelas VIII C dengan jumlah 32 siswa yang di ambil dari salah satu kelas VIII yang ada di SMP Negeri 2 Jenawi.

\section{Uji Validitas}

Validitas instrumen ini termasuk jenis validitas isi. Untuk mengetahui validitas digunakan rumus korelasi product moment yaitu dengan cara mengkorelasikan jumlah skor butir dengan jumlah skor total dengan rumus:

$r_{x y}=\frac{N x\left(\sum X Y\right)-\left(\sum X\right)\left(\sum Y\right)}{\sqrt{\left\{N \sum X^{2}-\left(\sum X\right)^{2}\right\}\left\{N \sum Y^{2}-\left(\sum Y\right)^{2}\right.}}$

Keterangan :

$r_{x y} \quad$ : Koefisien korelasi yang dicari

$\mathrm{N} \quad$ : Banyaknya subjek pemilik nilai

$\mathrm{X} \quad$ : Nilai Variabel 1

Y : Nilai Variabel 2

$\sum X Y \quad$ : Perkalian antara skor $\mathrm{x}$ dan $\mathrm{y}$

$\sum X^{2} \quad$ : Jumlah $x$ kuadrat

$\sum Y^{2}$ : Jumlah y kuadrat

$\sum X \quad$ : Jumlah $\mathrm{x}$ (jumlah skor butir)

$\sum Y \quad$ : Jumlah y (jumlah skor total)

Sumber (Arikunto, 2014, p. 327)

Uji coba dalam penelitian ini menggunakan responden siswa kelas VIII C SMP Negeri 2 Jenawi yang berjumlah 32 siswa, sehingga $r_{\text {tabel }}$ yang di dapatkan adalah sebesar 0,349. Kriteria penilaian butir angkat yang valid atau sahih apabila mempunyai $r_{\text {hitung }}>r_{\text {tabel }}$ $(0,349)$ dengan taraf signifikan $5 \%$ atau 0,05 .

Tujuan penelitian dapat dicapai melalui pengambilan data terhadap responden yang telah ditentukan. Data yang diperoleh dari hasil jawaban Quesioner Siswa kelas VIII SMP Negeri 2 Jenawi Kabupaten Karanganyar. Namun sebelum alat ukur diajukan dan dijawab responden penelitian, alat ukur di uji cobakan (try out). Try out dimaksudkan untuk mengetahui alat ukur yang digunakan valid atau tidak sebagai alat ukur penelitian.

\section{Uji Reliabilitas}

Uji reliabilitas ini dilakukan untuk mengetahui keandalan dari instrumen, analisis keandalan hanya dilakukan pada butir pernyataan yang dinyatakan sahih saja. Untuk menentukan reliabilitas instrumen mrnggunakan rumus Alpha Cronbarch yaitu:

$r_{11}=\frac{n}{n-1}\left(1-\frac{\sum \sigma_{t}^{2}}{\sigma_{t}^{2}}\right)$

Keterangan:

$r_{11}=$ Reliabilitas instrumen

$n \quad=$ Jumlah butir pernyataan

$\sigma_{t}^{2} \quad=$ Varian butir pernyataan

$\sigma_{t}^{2} \quad=$ Varian total 
Dalam perhitungan Quesioner (angket) selain mencari validitas juga reliabilitas, hal ini dimaksudkan untuk mengetahui keajegan dari Quesioner tersebut sebagai alat dalam penelitian.

Teknik analisis data yang digunakan pada penelitian ini adalah menggunakan statistik deskriptif sederhana yaitu menghitung frekuensi dan presentase yang disajikan adalam bentuk tabel. Statistik deskriptif adalah statistik yang digunakan untuk menganalisis data dengan cara mendeskripsikan atau menggambarkan data yang telah terkumpul sebagaimana adanya tanpa adanya membuat kesimpulan yang berlaku umum atau generalisasi. Rumus yang digunakan untuk mengetahui minat siswa SMP N 2 Jenawi Kabupaten Karanganyar adalah sebagai berikut:

$\mathrm{P}=\frac{\mathrm{F}}{\mathrm{N}} \times 100 \%$

Keterangan:

$P=$ Angka Presentase

$\mathrm{F}=$ Frekuensi

$\mathrm{N}$ = Jumlah / banyaknya individu

Proses analisis dengan meilakukan pengkategorian yang didasarkan pada PAP (Patokan Acuan Patokan). Menurut Soewito (2011: 17) menyatakan bahwa "Penelitian acuan patokan adalah penelitian yang membandingkan hasil belajar siswa kepada patokan yang telah ditetapkan sebelumnya". Untuk menentukan minat siswa dikategorikan menjadi 5 kategori yaitu sangat tinggi, tinggi, sedang, rendah dan sangat rendah. Rumus yang digunakan untuk menyusun kategori adalah sebagai berikut:
a. $X>M+1,5 S D$
b. $M+0,5 S D<X \leq M+1,5 S D(T)$
c. $M-0,5 S D<X \leq M+0,5 S D(S)$
d. $M-1,5 S D<X \leq M-0,5 S D(R)$
e. $X \leq M-1,5 S D$

Keterangan:

M : Mean

SD : Standar Deviasi

\section{HASIL DAN PEMBAHASAN}

\section{Hasil}

Hasil penelitian yang diperoleh melalui angket disajikan dalam bentuk tabel yang berisi deskripsi statistik, kategorisasi yang berisi frekuensi dan persentase dari setiap butir instrumen serta dilengkapi dengan uraian deskriptif. Dalam penyajian data, meskipun data setiap butir diusahakan ditampilkan secara berurutan berdasarkan jenis instrumen lain. Hal ini dilakukan untuk menjaga kesinambungan kontekstual dalam uraian deskriptif.

Deskripsi Hasil Faktor Perhatian dalam Minat Siswa Kelas VIII SMP Negeri 2 Jenawi Kabupaten Karanganyar Terhadap Pembalajaran Atletik Tabel 1.

Dari hasil analisis data penelitian yang dilakukan dapat dideskripsikan dalam betuk

Tabel 1. Berkaitan Dengan Kategorisasi Faktor Perhatian Siswa

\begin{tabular}{ccccc}
\hline \multicolumn{5}{c}{ INDIKATOR I } \\
\hline No & Kategori & Rentang Skor & Frekuensi Jawaban & Persentase \\
\hline 1 & Sangat Tinggi & $41,55<X$ & 0 & $0,00 \%$ \\
2 & Tinggi & $34,55-41,54$ & 16 & $16,00 \%$ \\
3 & Sedang & $27,55-34,54$ & 76 & $76,00 \%$ \\
4 & Kurang & $20,55-27,54$ & 8 & $8,00 \%$ \\
5 & Sangat Kurang & $X \leq 20,54$ & 0 & $0,00 \%$ \\
\hline \multicolumn{7}{c}{ Jumlah } & $\mathbf{1 0 0}$ & $\mathbf{1 0 0} \%$ \\
\hline
\end{tabular}


Dalam masing-masing kawasan tersebut masih dipilih lagi berdasarkan 5 komponen utama (1) Perhatian. (2). Ketertarikan Siswa. (3) Aktifitas (4) Guru. (5) Alat dan Fasilitas. Dalam setiap pertanyaan dibagi atas 4 pilihan jawaban yaitu jawaban $A$ atau nilai 4 (baik), jawaban B atau nilai 3 (cukup) dan jawaban $C$ atau nilai 2 (kurang), jawaban D atau nilai 1 (kurang sekali). Data disajikan dalam bentuk tabelstatistik dan tabel yang berisi frekuensi dan persentase dari setiap butir instrumen serta dilengkapi dengan uraian deskriptif .

Tabel 1 dapat di ketahui bahwa minat siswa SMP Negeri 2 Jenawi kelas VIII terhadap pembelajaran atletik yang berkaitan dengan faktor perhatian memiliki minat cukup, dengan kategori terbanyak berada pada kategori sedang sebanyak 76 dengan persentase $76 \%$. Faktor perhatian pada minat siswa kelas VIII SMP Negeri 2 Jenawi terhadap pembelajaran atletik berkategori sangat tinggi sebanyak 0 dengan persentase $0 \%$, kategori tinggi sebanyak 16 dengan persentase $16.00 \%$, kategori sedang sebanyak 76 dengan persentase $76.00 \%$, kategori kurang sebanyak 8 dengan persentase $8,00 \%$ dan kategori sangat kurang sebanyak 0 dengan persentase $0 \%$. Hasil tersebut apabila ditampilkan dalam Gambar 1.

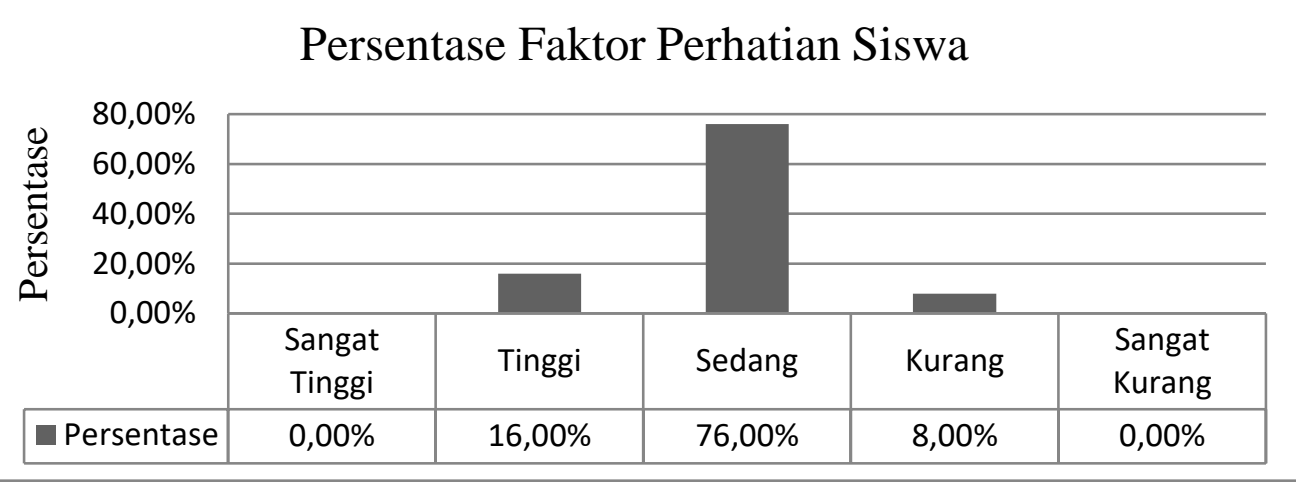

Gambar 1. Faktor perhatian pada minat siswa kelas VIII terhadap pembalajaran atletik di SMP Negeri 2 Jenawi Kabupaten Karanganyar

Faktor Ketertarikan Siswi Kelas VIII Terhadap Pembalajaran Atletik di SMP Negeri 2 Jenawi Tabel 2.

Dari hasil analisis data penelitian yang dilakukan dapat dideskripsikan dalam betuk

Tabel 2. Berkaitan dengan Kategorisasi Faktor Ketertarikan Siswa.

\begin{tabular}{ccccc}
\hline \multicolumn{5}{c}{ INDIKATOR II } \\
\hline No. & Kategori & Rentang Skor & Frekuensi Jawaban & Persentase \\
\hline 1. & Sangat Tinggi & $37,8<\mathrm{X}$ & 0 & $0,00 \%$ \\
2. & Tinggi & $30,3-37,7$ & 12 & $12,00 \%$ \\
3. & Sedang & $22,8-30,2$ & 76 & $76,00 \%$ \\
4. & Kurang & $15,3-22,7$ & 12 & $12,00 \%$ \\
5. & Sangat Kurang & $X \leq 15,2$ & 0 & $0,00 \%$ \\
\hline \multicolumn{7}{r}{ Jumlah } & & 100 & $100 \%$ \\
\hline
\end{tabular}

Tabel 2 dapat di ketahui bahwa minat siswi kelas VIII terhadap pembelajaran atletik yang berkaitan dengan faktor ketertarikan siswa memiliki minat cukup, dengan kategori terbanyak berada pada kategori sedang sebanyak 76 dengan persentase $76 \%$. Faktor ketertarikan pada minat siswa kelas VIII terhadap pembelajaran atletik berkategori sangat tinggi sebanyak 0 dengan persentase $0 \%$, kategori tinggi sebanyak 12 dengan persentase $12.00 \%$, kategori sedang sebanyak 76 dengan persentase $76.00 \%$, kategori kurang sebanyak 12 dengan persentase $12,00 \%$ dan kategori sangat kurang sebanyak 0 dengan persentase $0 \%$. Hal tersebut tersaji dalam gambar 2 . 
Jurnal Pendidikan Jasmani Indonesia, 15 (1), 2019 - 18

Maratona Sakti Utami, Eddy Purnomo

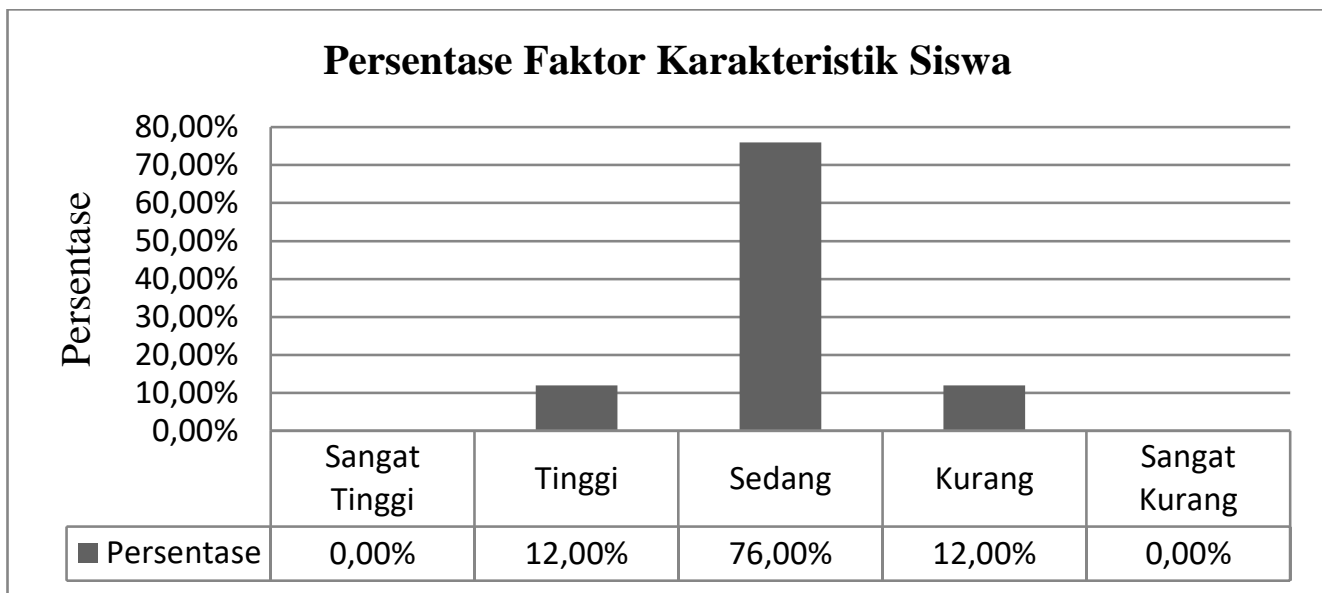

Gambar 2. Persentase faktor ketertarikan pada minat siswi kelas VIII terhadap pembalajaran atletik

Faktor Aktifitas Siswi Kelas VIII Terhadap Pembelajaran Pembalajaran Atletik

Dari hasil analisis data penelitian yang dilakukan dapat di deskripsikan dalam betuk tabel seperti berikut:

Tabel 3. Faktor Aktifitas Siswa Dalam Pembelajaran

\begin{tabular}{ccccc}
\hline \multicolumn{5}{c}{ INDIKATOR III } \\
\hline No. & Kategori & Rentang Skor & Frekuensi Jawaban & Persentase \\
\hline 1. & Sangat Tinggi & $47,24<X$ & 0 & $0,00 \%$ \\
2. & Tinggi & $36,74-47,23$ & 11 & $11,00 \%$ \\
3. & Sedang & $26,24-36,73$ & 83 & $83,00 \%$ \\
4. & Kurang & $15,74-26,23$ & 6 & $6,00 \%$ \\
5. & Sangat Kurang & $X \leq 15,73$ & 0 & $0,00 \%$ \\
\hline \multicolumn{7}{r}{ Jumlah } & & 100 & $100 \%$ \\
\hline
\end{tabular}

Tabel 3 di ketahui bahwa minat siswi kelas VIII terhadap pembelajaran atletik yang berkaitan dengan faktor aktifitas siswi memiliki minat cukup, dengan kategori terbanyak berada pada kategori sedang sebanyak 83 dengan persentase $83 \%$. Kategori sangat tinggi sebanyak 0 dengan persentase $0 \%$, kategori tinggi sebanyak 11 dengan persentase $11.00 \%$, kategori sedang sebanyak 83 dengan persentase $83.00 \%$, kategori kurang sebanyak 6 dengan persentase $6,00 \%$ dan kategori sangat kurang sebanyak 0 dengan persentase $0 \%$. Hasil tersebut dapat dilihat pada Gambar 3.

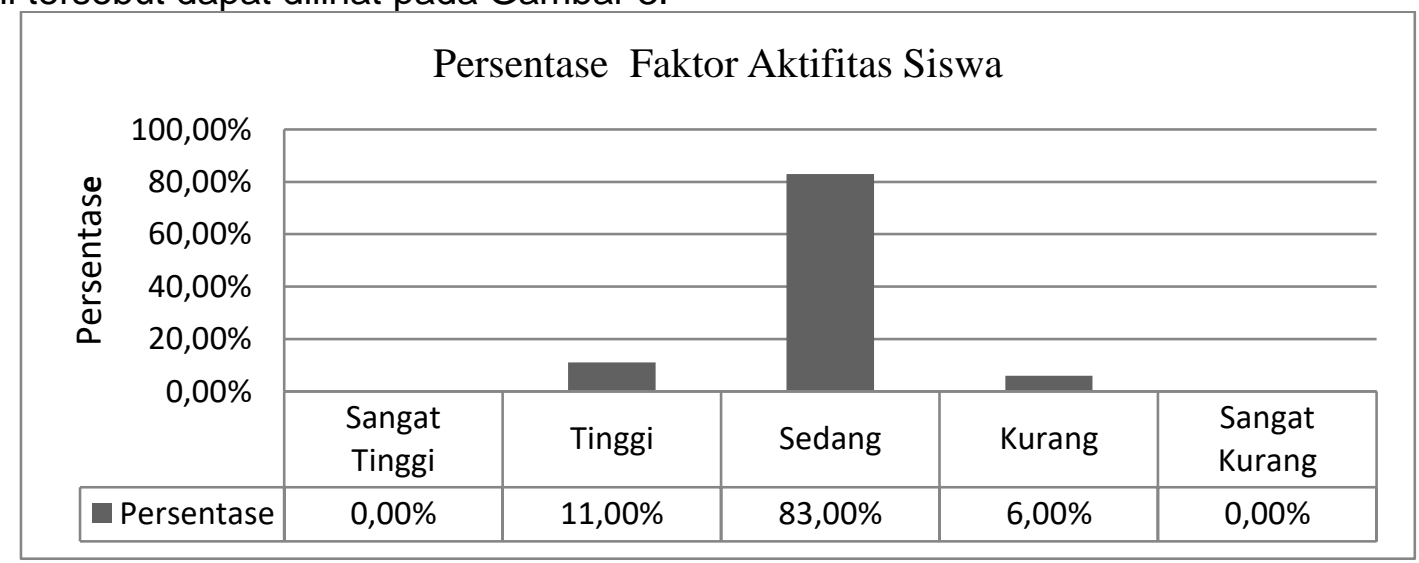

Gambar 3. Persentase faktor aktifitas pada minat siswa kelas VIII terhadap pembelajaran atletik

Faktor Guru Pengampu Kelas VIII Terhadap Pembalajaran Atletik 
Jurnal Pendidikan Jasmani Indonesia, 15 (1), 2019 - 19

Maratona Sakti Utami, Eddy Purnomo Tabel 4.

Dari hasil analisis data penelitian yang dilakukan dapat di deskripsikan dalam betuk

Tabel 4. Berkaitan dengan Faktor Guru Pengampu

\begin{tabular}{ccccc}
\hline \multicolumn{5}{c}{ INDIKATOR IV } \\
\hline No & Kategori & Rentang Skor & Frekuensi Jawaban & Persentase \\
\hline 1 & Sangat Tinggi & $32,68<X$ & 0 & $0,00 \%$ \\
2 & Tinggi & $27,68-32,67$ & 16 & $16,00 \%$ \\
3 & Sedang & $22,68-27,67$ & 65 & $65,00 \%$ \\
4 & Kurang & $17,68-22,67$ & 19 & $19,00 \%$ \\
5 & Sangat Kurang & $X \leq 17,67$ & 0 & $0,00 \%$ \\
\hline \multicolumn{7}{r}{ Jumlah } & & 100 & $100 \%$ \\
\hline
\end{tabular}

Tabel 4, dapat di ketahui bahwa minat siswi kelas VIII terhadap pembelajaran atletik yang berkaitan dengan faktor alat dan fasilitas memiliki minat cukup, dengan kategori terbanyak berada pada kategori sedang sebanyakk 77 dengan persentase $77 \%$. Kategori sangat tinggi sebanyak 0 dengan persentase $0 \%$, kategori tinggi sebanyak 16 dengan persentase $16.00 \%$, kategori sedang sebanyak 77 dengan persentase $77.00 \%$, kategori kurang sebanyak 7 dengan persentase $7,00 \%$ dan kategori sangat kurang sebanyak 0 dengan persentase $0 \%$.

Hasil tersebut apabila ditampilkan dalam bentuk gambar dapat dilihat sebagai berikut:

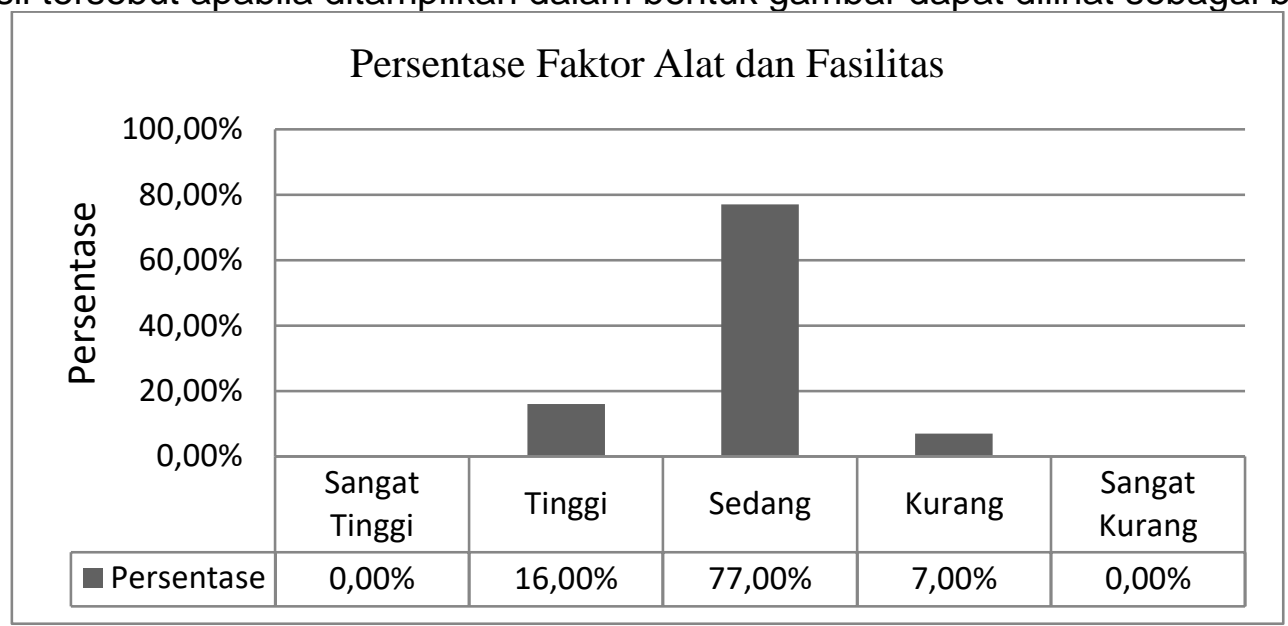

Gambar 5. Faktor alat dan fasilitas pada minat siswi kelas VIII terhadap pembalajaran atletik

\section{Pembahasan}

Berdasarkan analisis data hasil penelitian di peroleh bahwa minat siswi kelas VIII terhadap pembelajaran atletik adalah cukup, dengan persentase terbanyak pada faktor aktifitas siswa yaitu $83,00 \%$ dan berada pada kategori sedang. Dengan penjabaran hasil angket didapatkan bahwa berkaitan dengan aktifitas siswa saat ini dengan kategori sangat tinggi sebanyak 0 dengan persentase $0,00 \%$, kategori tinggi sebanyak 11 dengan persentase $11.00 \%$, kategori sedang sebanyak 83 dengan persentase $83.00 \%$, kategori kurang sebanyak 6 dengan persentase $6,00 \%$ dan kategori sangat kurang sebanyak 0 dengan persentase $0,00 \%$. Dari data di atas dapat di simpulkan bahwa faktor intrinsik lebih besar peranannya di bandingkan dengan faktor ekstrinsik. Hasil tersebut dipengaruhi oleh beberapa faktor, yaitu: (1) Sebagian besar siswa kelas VIII SMP Negeri 2 Jenawi Kabupaten Karanganyar, sudah cukup baik perhatiannya dalam mengikuti pembelajaran Penjasorkes di sekolah; (2) Terlihat sebagian besar siswa kelas VIII SMP Negeri 2 Jenawi Kabupaten Karanganyar, bersemangat dalam mengikuti aktivitas pembelajaran Penjasorkes di sekolah; (3) Pembelajaran Penjasorkes di kelas VIII SMP Negeri 2 Jenawi Kabupaten Karanganyar mendapat respon yang positif dari hampir sebagian besar siswi; (4) Guru di SMP Negeri 2 Jenawi Kabupaten Karanganyar dalam penyampaian materi pembelajaran Penjasorkes sudah baik; (5) Ketersediaan sarana prasarana dan fasilitas 
pembelajaran Penjasorkes yang kurang memadai dalam pembelajaran atletik kelas VIII SMP Negeri 2 Jenawi Kabupaten Karanganyar.

Permasalahan yang sering muncul dalam pembelajaran atletik harus mampu di minimalisir oleh guru agar siswa memiliki minat atau rasa tertarik dalam diri siswa untuk mengikuti pembelajaran atletik di sekolah dengan aktif. Djaali (2007, p.69) menyatakan bahwa minat adalah rasa lebih suka dan rasa ketertarikan pada suatu hal atau altivitas, tanpa ada yang menyuruh. Minat pada dasarnya adalah penerimaan akan suatu hubungan antara diri sendiri dengan sesuatu di luar diri. Semakin kuat atau dekat hubungan tersebut, semakin besar minatnya. Peranan guru dalam pembalajaran sangatlah penting untuk mengemas pembelajaran dan mengontrol kondisi kelas. Hal ini menu jukkan bahwa seorang guru harus mampu menciptakan suasana pembelajaran yang mmenyenangkan dengan memanfaatkan fasilitas yang ada dan mengontrol psikologis siswa agar siswa memiliki minat belajar yang tinggi.

Menurut Slameto (2015, p. 180) menyatakan bahwa minat adalah rasa lebih suka dan rasa tertarik pada suatu hal atau aktivitas tanpa ada yang menyuruh. Dengan adanya pembelajaran atletik yang sudah di modifikasi oleh guru, siswa akan merasa senang dan akan terbentuk minat belajar yang tinggi dalam diri siswa. minat belajar yang tinggi akan membantu siswa untuk aktif dalam pembelajaran dan memiliki kesempatan untuk menguasai keterampilan yang diajarkan dan meraih prestasi belajar dengan maksimal.

\section{SIMPULAN}

Berdasarkan hasil penelitian dan pembahasan yang telah dipaparkan maka dapat diambil kesimpulan bahwa minat siswi kelas VIII terhadap pembelajaran atletik di SMP Negeri 2 Jenawi Kabupaten Karanganyar adalah cukup dengan persentase terbanyak berada pada kategori sedang, sebesar $83,00 \%$. Minat siswa kelas VIII terhadap pembelajaran atletik di SMP Negeri 2 Jenawi Kabupaten Karanganyar yang memiliki persentase paling besar terdapat pada faktor intrinsik yaitu pada aktifitas siswa. Adapun pada kategori sangat tinggi dengan persentase sebesar $0,00 \%$, kategori tinggi dengan persentase sebesar $11,00 \%$, kategori sedang dengan persentase sebesar $83,00 \%$, kategori kurang dengan persentase sebesar $6,00 \%$ dan kategori sangat kurang dengan persentase sebesar $0,00 \%$.

\section{DAFTAR PUSTAKA}

Arikunto, S. (2006). Prosedur penelitian suatu pendekatan praktek. Jakarta : Rineka Cipta.

Arikunto, S. (2014). Manajemen penelitan. Jakarta: PT Rineka Cipta.

Basri, J. (2018). Mutu dan kesejahteraan guru di Indonesi. Jurnal Pendidikan Islam Rabbani, 2(1).

Djaali, H. (2007). Psikologi pendidikan. Jakarta: PT Bumi Aksara.

Hari, S.D. (2007). Minat siswa SMK YPKK 2 Sleman kelas XI terhadap pembelajaran atletik. Skripsi, tidak diterbitkan, Universitas Negeri Yogyakarta, Yogyakarta.

Montessori, M. (2012). Pendidikan antikorupsi sebagai pendidikan karakter di sekolah. Jurnal Demokrasi, 11(1).

Murdiyanto, A. S. (2010). Penerapan pendekatan bermain untuk meningkatkan hasil belajar lompat jangkit pada siswa kelas xii ipa 3 SMA Negeri 4 Surakarta tahun pelajaran 2010/2011 (Doctoral dissertation, Universitas Sebelas Maret).

Riduwan. (2009). Pengantar statistika sosial. Bandung: Alfabeta.

Slameto. (2015). Belajar dan faktor-faktor yang mempengaruhi (Rev.ed.). Jakarta: Rineka Cipta.

Soewito, N. (2011). Evaluasi pembelajaran pendidikan jasmani. Yogyakarta: FIK UNY Yogyakarta. 
Sudarsana, I. K. (2016). Pemikiran tokoh pendidikan dalam buku lifelong learning: policies, practices, and programs (Perspektif peningkatan mutu pendidikan di Indonesia). Jurnal Penjaminan Mutu, 2(2), 44-53.

Wibowo, M. G. A. (2017). Keadaan sarana dan prasarana pembelajaran pendidikan jasmani di sekolah dasar se-Gugus Sumberagung Kecamatan Moyudan Kabupaten Sleman. PGSD Penjaskes, (3). 